University of South Florida

DIGITAL COMMONS

Digital Commons @ University of

@ UNIVERSITY OF SOUTH FLORIDA

South Florida

$1-1-2010$

\title{
2010 Work Plan USF Sarasota-Manatee
}

USF

Follow this and additional works at: https://digitalcommons.usf.edu/usf_accountability_reports

\section{Scholar Commons Citation}

USF, "2010 Work Plan USF Sarasota-Manatee" (2010). USF Accountability Reports. 12.

https://digitalcommons.usf.edu/usf_accountability_reports/12

This Article is brought to you for free and open access by the USF Archives at Digital Commons @ University of South Florida. It has been accepted for inclusion in USF Accountability Reports by an authorized administrator of Digital Commons @ University of South Florida. For more information, please contact digitalcommons@usf.edu. 


\section{University Work Plan / Proposal}

\section{University of South Florida Sarasota-Manatee}

\section{Strategic Plan}

[Please provide a link to the latest version of the institution's strategic plan. If the latest strategic plan is not current, or the institution is in the process of developing or updating its strategic plan, please indicate at what stage the institution is in that process.]

USF Sarasota-Manatee will update its 2006-11 Strategic Plan following completion of the separate accreditation process, projected as June 2011.

http:// www.sarasota.usf.edu/Alpha/IR/Strategic_Plan/0809Update/Update_2008-09.htm

\section{Mission Statement}

The University of South Florida Sarasota-Manatee delivers quality education to upper-division baccalaureate and master's students in an active research environment. We support students in attaining their highest potential by nurturing leadership, critical thinking, and an appreciation for learning. We advance cultural, social, environmental, and economic well-being for all we serve.

\section{Overview of Core Institutional Strengths, Special Assets, and Niche Contributions}

\section{Strengths:}

I. Community Engaged University

a. The USF Sarasota-Manatee Community Leadership Council, comprised of local area community and business leaders many of whom are USF alumni, advises the Campus Board and the Regional Chancellor's Executive Council about the unique needs of Sarasota and Manatee Counties.

b. USF Sarasota-Manatee's College of Education (COE) recently entered into partnership with Manatee County on a third professional development school within the county.

c. USF Sarasota-Manatee proudly partners with local community foundations such as the Gulf Coast Community Foundation of Venice, Community Foundation of Sarasota, William G. Selby and Marie Selby Foundation, and the Knight Foundation.

d. Institute for Public Policy \& Leadership fills the community-recognized need for an informed, non-partisan setting to critically and reflectively examine policy. Also, the institute provides educational experiences to public officials and citizens to enable them to more effectively serve and contribute to the public trust.

e. For the second year, USF Sarasota-Manatee will host the STEM (Science, Technology, Engineering, Math) Girls Summit. The program was the brain-child of a USF Sarasota-Manatee student. The summit, held in partnership with the American Association of University Women, provides middle-school girls the opportunity to explore careers in the STEM fields.

f. Faculty engage in community-based, applied research with Mote Marine, Sarasota Memorial Hospital, Jewish Children and Family Services, Senior Friendship Center, and SCOPE 
II. Delivery of Outstanding Educational Programs

a. Despite its consistent growth, USF Sarasota-Manatee continues to keep class sizes small. Students enjoy a 19-to-1 student-to-faculty ratio, as reported through the Integrated Postsecondary Education Data System (IPEDS).

b. The faculty of USF Sarasota-Manatee are highly collaborative with research foci that break across the typical department lines and result in forward-thinking interdisciplinary studies.

c. Each semester over $70 \%$ of USF Sarasota-Manatee credit hours are taught by full-time faculty.

d. USF Sarasota-Manatee's degree programs provide extensive opportunities for field work and internships. Beyond the typical, USF Sarasota-Manatee offers these experiences in each of its Colleges and School.

e. USF Sarasota-Manatee strives to be a leader in "quality" online education by delivering much of its online course work in blended formats. Blending ensures that students have the flexibility of online scheduling while still experiencing the mentorship and collaboration of the face-to-face environment.

\section{Special Assets}

I. State-of-the-Art Facility

a. The architecturally spectacular USF Sarasota-Manatee Campus is located on U.S. 41 (Tamiami Trail) about a half-mile north of University Parkway on the border of Sarasota and Manatee Counties near Sarasota Bay, the Powel Crosley Mansion, the John \& Mable Ringling Museum of Art, and the Sarasota-Bradenton International Airport. The 100,000-square-foot, state-of-the-art academic facility houses 24 classrooms, a 190-seat lecture/exhibition hall, seminar rooms, computer labs, student gathering places, faculty and staff offices, a technology and learning center, and dining facilities.

b. Technically, the campus stands out with its smart classrooms, wireless teaching labs, technology training labs, and campus-wide access to a high-speed, wireless network.

\section{Current Peer Institutions}

USF Sarasota-Manatee will complete a list of peer institutions following the completion of the separate accreditation process, projected for June 2011. 
Institutional Vision and Strategic Directions for the Next 5 - 10 Years

Strategic Directions (Next 5-10 years):

1. Learner-Centered Environment: Be a diverse, collaborative, and intellectually challenging campus with high quality academic programs and support services for students, faculty, staff, and community.

With strategic focus on teaching and learning, research, programming, campus climate and community USF Sarasota-Manatee has met and seeks to exceed its objectives for this goal.

- Presently, 70\% of USF Sarasota-Manatee student credit hours (SCH) are taught by fulltime resident faculty. The campus will maintain this percentage with a goal of improving the ratios once funding for additional faculty members becomes available.

- USF Sarasota-Manatee met all enrollment targets in the academic year 2008-09. In 2009-10, USF Sarasota-Manatee enrollment goals are set to increase undergraduate student credit hours by 9\% over 2008-09 funded levels.

2. Technology: Provide and encourage strategic use of electronic learning technology.

Student convenience and teaching and learning enhancement foci have resulted in a $16 \%$ increase in the number of distance learning course in 2009-10 over 2008-09 levels.

USF Sarasota-Manatee will continue to focus curricular efforts on using technology to develop convenient schedules for student learning, such as online course, distance learning, and hybrid courses.

3. Program Growth: Promote expansion of distinctive upper-division baccalaureate, master's, and research initiatives that serve local and global needs.

Through the efforts of seeking separate accreditation, USF Sarasota-Manatee has worked to ensure degree programs are complete and that students have access to resident faculty and a full course schedule to ensure timely degree obtainment.

USF Sarasota-Manatee plans to increase the number of programs it offers the community in the near future. In concert with the 2010 census data, USF Sarasota-Manatee will conduct a comprehensive environmental scan of the three-county area to identify educational needs and growing markets.

4. Professional and Continuing Education: Provide advanced professional and continuing education that serves community needs.

Academic year 2009-10 has been an exciting year of growth in continuing and professional education on campus. For instance, USF Sarasota-Manatee's College of Business recently partnered with the Nonprofit Resource Center of the Community Foundation of Sarasota County to deliver a comprehensive training program for nonprofit leaders.

Faculty are also exploring professional and continuing education in professional human services/aging workers, accountants, and business professionals.

Aspirational Peer Institutions (aspire and plan to be comparable to in the next 5 - 10 years) USF Sarasota-Manatee will complete a list of aspirant peer institutions following the completion of the separate accreditation process, projected for June 2011. 


\begin{tabular}{|c|c|c|c|c|}
\hline Projected Institutional Contributions to System-Level Goals \\
\hline \multicolumn{5}{|c|}{ NUMERIC TARGETS } \\
\hline Dashboard Metric & Date & Actual Value & Date & Projected Value \\
\hline Baccalaureate Degrees Awarded & $2008-09$ & 450 & $2012-13$ & 438 \\
\hline
\end{tabular}

\section{Notes:}

USF Sarasota-Manatee began the process of seeking separate accreditation in 2009. In Fall 2009, USF Tampa mandated that any USF Sarasota-Manatee student in degree programs hosted by USF Tampa or not offered completely by USF Sarasota-Manatee be removed from USF Sarasota-Manatee Home Campus enrollment numbers. As a result, USF Sarasota-Manatee saw decreases in the both Home Campus headcounts and the number of degrees awarded to students through the Sarasota-Manatee campus.

In addition to the loss of programs, USF Sarasota-Manatee is also unable to start new programming until after the separate accreditation process. In 2009-10, the number of degrees awarded by USF Sarasota-Manatee is estimated to be 384 . Using a consistent growth rate of $4.5 \%$ the campus projects it will return to the level of degrees awarded in 2008-09 by 2012-13, pending the achievement of separate accreditation and increases in the campus resource base.

\begin{tabular}{|l|l|l|l|l}
\hline Master's Degrees Awarded & $2008-09$ & 125 & $2012-13$ & 77 \\
\hline
\end{tabular}

\section{Notes:}

USF Sarasota-Manatee began the process of seeking separate accreditation in 2009. In Fall 2009, USF Tampa mandated that any USF Sarasota-Manatee student in degree programs hosted by USF Tampa or not offered completely by USF Sarasota-Manatee be removed from USF Sarasota-Manatee Home Campus enrollment numbers. As a result, USF Sarasota-Manatee saw decreases in the both Home Campus headcounts and the number of degrees awarded to students through the Sarasota-Manatee campus.

In addition to the loss of programs, USF Sarasota-Manatee is also unable to start new programming until after the separate accreditation process. Therefore, it is likely that the number of degrees awarded at the graduate level will remain consistent with the estimated 2009-10 level of 75 degrees awarded, pending the achievement of separate accreditation and increases in the campus resource base.

\begin{tabular}{|c|c|c|c|c|}
\hline $\begin{array}{l}\text { Research and Professional } \\
\text { Doctorates Awarded }\end{array}$ & $2008-09$ & 0 & $2012-13$ & 0 \\
\hline $\begin{array}{l}\text { Federal Academic Research and } \\
\text { Development Expenditures }\end{array}$ & $2007-08$ & SYSTEM ONLY & 2011-12 & SYSTEM ONLY \\
\hline $\begin{array}{l}\text { Total Academic Research and } \\
\text { Development Expenditure }\end{array}$ & $2007-08$ & SYSTEM ONLY & 2011-12 & SYSTEM ONLY \\
\hline \multirow{2}{*}{$\begin{array}{l}\text { FTIC }^{* * *} \text { Six-Year Retention and } \\
\text { Graduate Rates from the Same IHE }\end{array}$} & \multirow{2}{*}{$\begin{array}{l}2003-09 \\
\text { FTIC } \\
\text { Cohort }\end{array}$} & $\begin{array}{c}\text { Graduated } \\
\text { N/A }\end{array}$ & \multirow{2}{*}{$\begin{array}{c}2007-13 \\
\text { FTIC } \\
\text { Cohort }\end{array}$} & $\begin{array}{c}\text { Graduated } \\
\text { N/A }\end{array}$ \\
\hline & & $\begin{array}{l}\text { Still Enrolled } \\
\text { N/A }\end{array}$ & & $\begin{array}{l}\text { Still Enrolled } \\
\text { N/A }\end{array}$ \\
\hline \multirow{2}{*}{$\begin{array}{l}\text { AA Transfer*** Four-Year } \\
\text { Retention and Graduation Rates } \\
\text { from the Same IHE }\end{array}$} & \multirow{2}{*}{$\begin{array}{l}\text { 2005-09 } \\
\text { AAT } \\
\text { Cohort }\end{array}$} & $\begin{array}{l}\text { Graduated } \\
63.0 \%\end{array}$ & \multirow{2}{*}{$\begin{array}{l}2009-13 \\
\text { AAT } \\
\text { Cohort }\end{array}$} & $\begin{array}{l}\text { Graduated } \\
63.0 \%\end{array}$ \\
\hline & & $\begin{array}{l}\text { Still Enrolled } \\
13.0 \%\end{array}$ & & $\begin{array}{l}\text { Still Enrolled } \\
\quad 13.0 \%\end{array}$ \\
\hline
\end{tabular}

Notes: USF Sarasota-Manatee began the process of seeking separate accreditation in 2009. In Fall 2009, USF Tampa mandated that any USF Sarasota-Manatee student in degree programs hosted by USF Tampa or not offered completely by USF Sarasota-Manatee be removed from USF Sarasota-Manatee Home Campus enrollment numbers. As a result of this mandate, USF Sarasota-Manatee will be at a disadvantage when attempting to increase retention and/or graduation rates. 
DIRECTIONAL TARGETS [Indicate Direction: I=Increase, M=Maintain, D=Decrease]

\begin{tabular}{|c|c|c|c|c|c|c|}
\hline Dashboard Metric & Date & \multicolumn{2}{|c|}{ Actual Value } & Date & \multicolumn{2}{|c|}{ Projected Direction** } \\
\hline Baccalaureate Deg & \multirow{2}{*}{ 2008-09 } & \# & $\% *$ & \multirow{2}{*}{ 2012-13 } & \# & $\%$ * \\
\hline to Black, Non-Hispanics & & 26 & $5.9 \%$ & & I & I \\
\hline
\end{tabular}

Notes: The projected increase in number of degrees awarded to minority students is consistent with the mission and vision of USF Sarasota-Manatee in which the campus strives to advance the "cultural, social, environmental, and economic well-being" for all members of its community.

\begin{tabular}{l|c|c|c|c|c|c|c|}
\hline Baccalaureate Degrees Awarded & \multirow{2}{*}{$2008-09$} & $\#$ & $\%^{*}$ & \multirow{2}{*}{$2012-13$} & $\#$ & $\%^{*}$ \\
\cline { 3 - 4 } & & 27 & $6.2 \%$ & & I & I \\
\hline
\end{tabular}

Notes: The projected increase in number of degrees awarded to minority students is consistent with the mission and vision of USF Sarasota-Manatee in which the campus strives to advance the "cultural, social, environmental, and economic well-being" for all members of its community.

\begin{tabular}{l|c|c|c|c|c|c|c|}
\hline Baccalaureate Degrees Awarded & \multirow{2}{*}{$2008-09$} & $\#$ & $\%^{*}$ & \multirow{2}{*}{$2012-13$} & $\#$ & $\%^{*}$ \\
\cline { 3 - 4 } & & & 158 & $36.3 \%$ & & I & I \\
\hline
\end{tabular}

Notes: The projected increase in number of degrees awarded to students seeking financial aid is consistent with the mission and vision of USF Sarasota-Manatee in which the campus strives to advance the "cultural, social, environmental, and economic well-being" for all members of its community.

\begin{tabular}{l|c|c|c|c|c|c|}
\hline Degrees Awarded in Specified & \multirow{2}{*}{$2008-09$} & Bacc. & Grad. & \multirow{2}{*}{$2012-13$} & Bacc. & Grad. \\
\cline { 3 - 4 } \cline { 5 - 7 } \\
\cline { 5 - 6 }
\end{tabular}

Notes: USF Sarasota-Manatee does not currently have a STEM related program at the graduate level.

\begin{tabular}{|l|c|c|c|c|c|c|}
\hline $\begin{array}{l}\text { Degrees Awarded in Specified } \\
\text { Health Profession Critical Need } \\
\text { Areas }\end{array}$ & \multirow{2}{*}{$2008-09$} & Bacc. & Grad. & \multirow{2}{*}{$2012-13$} & Bacc. & Grad. \\
\cline { 3 - 4 } \cline { 6 - 8 } & & 16 & 7 & & D & D \\
\hline
\end{tabular}

Notes: USF Sarasota-Manatee does not grant degrees within the Health Profession Critical Needs Area. USF Tampa awards degrees to nursing students taking course work through the USF Sarasota-Manatee campus.

\begin{tabular}{|l|c|c|c|c|c|c|}
\hline Degrees Awarded in Specified & \multirow{2}{*}{$2008-09$} & Bacc. & Grad. & \multirow{2}{*}{$2012-13$} & Bacc. & Grad. \\
\cline { 7 - 8 } & & 11 & 13 & & D & D \\
\hline
\end{tabular}

Notes: USF Sarasota-Manatee's Special Education program was placed on moratorium because of low enrollments and lack of funding for faculty. Once demand for the program from the community returns, the program is planned for reinstatement.

\begin{tabular}{|c|c|c|c|c|}
\hline $\begin{array}{l}\text { NCLEX Pass Rate for First-Time } \\
\text { Test Takers in Baccalaureate } \\
\text { Nursing Program }\end{array}$ & 2008 & $\mathrm{~N} / \mathrm{A}$ & 2012 & $\mathrm{~N} / \mathrm{A}$ \\
\hline Licensing Income & $2007-08$ & SYSTEM ONLY & 2011-12 & SYSTEM ONLY \\
\hline Licenses and Options Executed & 2007-08 & SYSTEM ONLY & 2011-12 & SYSTEM ONLY \\
\hline \multirow{2}{*}{$\begin{array}{l}\text { Other Transfer }{ }^{* * *} \text { Five-Year } \\
\text { Retention and Graduation Rates } \\
\text { from the Same IHE }\end{array}$} & \multirow{2}{*}{$\begin{array}{l}\text { 2004-09 } \\
\text { Other } \\
\text { Cohort }\end{array}$} & $\begin{array}{c}\text { Graduated } \\
58.1 \%\end{array}$ & \multirow{2}{*}{$\begin{array}{l}\text { 2008-13 } \\
\text { Other } \\
\text { Cohort }\end{array}$} & $\begin{array}{c}\text { Graduated } \\
\text { M }\end{array}$ \\
\hline & & $\begin{array}{c}\text { Still Enrolled } \\
4.7 \%\end{array}$ & & $\begin{array}{c}\text { Still Enrolled } \\
\text { M }\end{array}$ \\
\hline
\end{tabular}

Notes: USF Sarasota-Manatee began the process of seeking separate accreditation in 2009. In Fall 2009, USF Tampa mandated that any USF Sarasota-Manatee student in degree programs hosted by USF Tampa or not offered completely by USF Sarasota-Manatee be removed from USF Sarasota-Manatee Home Campus enrollment numbers. As a result of this mandate, USF Sarasota-Manatee will be at a disadvantage when attempting to increase retention and/or graduation rates.

"Actual Value" should equal related value in 2009 Annual Report.

* Percentage of Total Baccalaureates Awarded That Were Awarded to Specific Group.

** Projected Direction = INCREASE, MAINTAIN, or DECREASE. 


\section{Additional Primary Institutional Goals/Metrics for the Next One to Three Years}

(In the context of the institutional strategic plan and vision, as well as System priorities, present a minimum of three additional goals on which university effort will be focused in the next one to three years. Describe each goal, including whether the goal is new or continuing, the strategy for achieving that goal, the metrics by which success will be measured, specific actions to be taken in this fiscal year, expected outcomes, and assumptions, including financial, upon which the projected outcomes are predicated.)

\section{Accreditation: Work toward institutional autonomy within the USF System with} separate regional and professional accreditations.

In 2009, USF Sarasota-Manatee began the work of documenting compliance with the standards and requirements of the Southern Association of Colleges and Schools (SACS). In 2010, the institution will continue this work and is hopeful a positive decision from the accrediting body will be made by June 2011.

In addition, USF Sarasota-Manatee will also seek separate national accreditation from the Association to Advance Collegiate Schools of Business (AACSB) and the National Council for Accreditation of Teacher Education (NCATE).

Separate accreditation, apart from USF Tampa, is a continuing goal of USF SarasotaManatee.

Strategy: USF Sarasota-Manatee will continue to document and report compliance with the standards of SACS, AACSB, and NCATE

Metrics: Granting of separate accreditation by SACS in June 2011. Submission of AACSB Maintenance Review Application annually and development of NCATE application materials.

Outcomes: USF Sarasota-Manatee is committed to upholding the highest standards of teaching, research, and service, and earning separate accreditation will show the world the strength of our students, faculty, and staff.

\section{Financial Stability: Grow and diversify the resource base.}

USF Sarasota-Manatee lost \$5.96 million in recurring funding from the State of Florida over the last three years. USF Sarasota-Manatee is seeking restoration of these funds in order to have a successful application for separate accreditation to the Southern Association of Colleges and Schools, particularly in the areas of adequate number of faculty and adequate student support resources.

Financial Stability is a continuing goal for the campus.

Strategy: USF Sarasota-Manatee administrators will work with local representatives to seek inclusion in spending bill.

Metrics: Funding of the $\$ 5.96$ million request by legislature.

Outcomes: USF Sarasota-Manatee will fund additional faculty members, growing the fulltime to part-time instructor ratio and thereby strengthening programs as well as increasing course offerings to students. 


\section{Assessment: Expand the system of self-study and continuous improvement.}

In January of 2009, USF Sarasota-Manatee hired a full-time staff member in Institutional Research \& Effectiveness (IR) to coordinate assessment on the campus. Academic and administrative units work with the IR to continually improve their programs and services through targeted objectives and valid and reliable means of assessment.

Assessment is a continuing goal for the campus.

Strategy: USF Sarasota-Manatee's Institutional Research and Effectiveness will continue to work with each academic and administrative unit to ensure proper reporting of goals, measures, and outcomes.

Metrics: Each academic and administrative unit will continue to follow annual assessment plans.

Outcomes: The Southern Association of Colleges and Schools (SACS) will grant separate accreditation to USF Sarasota-Manatee predicated on the solid assessment system. 


\begin{tabular}{|c|c|c|l|l|}
\hline $\begin{array}{c}\text { New Academic Degree Program Proposals - Next Three Years (Program development } \\
\text { goals need to align with the institutional strategic plan and System priorities.) }\end{array}$ \\
\hline $\begin{array}{c}\text { Proposed Date } \\
\text { of Submission to } \\
\text { University Board } \\
\text { of Trustees }\end{array}$ & $\begin{array}{c}\text { Program } \\
\text { Level }\end{array}$ & $\begin{array}{c}\text { 6-Digit } \\
\text { CIP } \\
\text { Code }\end{array}$ & \multicolumn{1}{|c|}{ Program Title } & \multicolumn{1}{c|}{$\begin{array}{c}\text { Comments } \\
\text { (Including Proposed } \\
\text { Implementation Date) }\end{array}$} \\
\hline Fall 2010 & MS & 52.0901 & Hospitality Management & Fall 2011 \\
\hline Fall 2010 & BA & 51.0201 & $\begin{array}{l}\text { Communication Sciences } \\
\text { Disorders }\end{array}$ & Fall 2011 \\
\hline Fall 2010 & BS & 30.1801 & $\begin{array}{l}\text { Interdisciplinary Natural } \\
\text { Sciences }\end{array}$ & Fall 2011 \\
\hline Fall 2011 & BS & 01.0303 & Aquaculture & Fall 2012 \\
\hline Fall 2011 & MA & 44.0000 & Human Services & Fall 2012 \\
\hline Fall 2011 & BS & 13.1206 & B.S. in Education & Fall 2012 \\
\hline Fall 2011 & MS & 52.1005 & $\begin{array}{l}\text { Human Resource } \\
\text { Development }\end{array}$ \\
\hline Fall 2012 & BS & 19.0799 & Generational Studies & Fall 2013 \\
\hline Fall 2012 & MEd & 13.0501 & Educational Technology & Fall 2013 \\
\hline
\end{tabular}




\section{Windows of Opportunity/Unique Challenges}

(If the university has been presented with one or more unique opportunities that have not been included in prior plans but which will receive particular attention during this year, those opportunities should be presented here. Additionally, if the university expects to face a unique challenge in the coming year(s), that should be noted.)

Opportunities

1. New Instructional Site in North Port USF Sarasota-Manatee will move its South County Instructional Site from the grounds of the State College of Florida, Manatee-Sarasota Venice Campus to a new site within the City of North Port. The new site will be operational Fall Semester 2010.

Challenges

1. State College System and Private Higher Education

a. Increased competition in local market.

b. Potential for duplication of programs/services.

2. Financial Resources -

USF Sarasota-Manatee lost \$5.96 million in recurring funding from the State of Florida over the last three years. USF Sarasota-Manatee will be seeking restoration of these funds in order to have a successful application for separate accreditation to the Southern Association of Colleges and Schools, particularly in the areas of adequate number of faculty and adequate student support resources. 


\section{Tuition Differential Proposal for 2010-2011}

University: University of South Florida Sarasota-Manatee

\section{Effective Date}

\begin{tabular}{|l|l|}
\hline University Board of Trustees Approval Date: & \\
\hline Implementation Date (month/year): & August 2010 \\
\hline
\end{tabular}

\section{Purpose}

\begin{tabular}{|l|l} 
Describe the overall purpose of the tuition & Increase course offerings.
\end{tabular}

differential at this institution and the aspects of

undergraduate education the funds are intended to improve.

\section{Campus or Center Location}

Campus or Center Location to which the Tuition $\quad$ Entire University

Differential fee will apply. (If the entire university, indicate as such.)

\section{Undergraduate Course(s)}

Course(s). (If the tuition differential fee applies to all university undergraduate courses, indicate as such. If not, also provide a rationale for the differentiation among courses.)

\section{Current Base Tuition and Tuition Differential Fee}

Current (2010-11) Undergraduate Base Tuition per credit hour:

Current Undergraduate Tuition Differential per credit hour:

$\$ 95.67$

$\$ 12.80$

\section{Proposed Increase in the Tuition Differential Fee}

Percentage tuition differential fee increase (calculated as a percentage of the sum of base tuition plus tuition differential): $\$$ Increase in tuition differential per credit hour: $\$$ Increase in tuition differential for 30 credit hours:
$7 \%$ $\$ 7.06$

$\$ 211.80$




\section{Projected Differential Revenue Generated and Intended Uses}

Incremental differential fee revenue generated in 2010-11 (projected): $\$ 256,935$

Total differential fee revenue generated in 2010-11 (projected):

$\$ 429,618$

Seventy percent $(\mathbf{7 0} \%)$ of the total differential revenue generated must be used for undergraduate education. The total estimated amount to be spent on undergraduate education is $\$ 300,733$

Describe in detail the initiative(s) and the estimated expenditure(s) for each:

1. Increase course offerings.

Thirty percent $(30 \%)$ of the total differential revenue generated must be used for undergraduate students who have financial need. Total estimated amount to be spent on financial need is $\$$. If private sources are to be used, then the estimated amount of private dollars to be raised to offset the fee revenue is $\$$.

Managed at the USF System Level (See USF System Work Plan)

\section{Monitoring}

Indicate how the university will monitor the success of the tuition differential fee. Provide specific performance metrics that will be used. Also, point out any metrics that are different from the prior year and any prior year metrics that are no longer listed.

1. Number of courses added.

\section{Performance Measure Status}

What is the institution's plan for improving performance on the identified measure(s)? Show initial/baseline data starting with the year before each metric was identified, the goal for each metric, time frame for achieving the goal, and where the institution is now in relation to the goal if not in the initial year.
1. Spring Semester 2010, 29 courses were funded by the tuition differential. 40 courses will be funded in Fall 2010. 


\section{Tuition Differential Supplemental Information}

Provide the following information for the 2009-2010 academic year.

\section{9-2010 - 70\% Initiatives (List the initiatives provided in} the 2009-10 tuition differential request.)

\section{University Update on Each Initiative}

Increase number of course offerings.

29 courses were funded in Spring

Semester 2010.

\section{Additional Detail, where applicable}

\begin{tabular}{|l|l|}
\hline $\begin{array}{l}\text { Number of Faculty Hired or Retained (funded by tuition } \\
\text { differential): }\end{array}$ & $\begin{array}{l}19 \text { adjunct faculty and } 2 \text { resident } \\
\text { faculty overloads were funded. }\end{array}$ \\
\hline $\begin{array}{l}\text { Number of Advisors Hired or Retained (funded by tuition } \\
\text { differential): }\end{array}$ & 0 \\
\hline $\begin{array}{l}\text { Number of Course Sections Added or Saved (funded by } \\
\text { tuition differential): }\end{array}$ & 29 \\
\hline
\end{tabular}

2009-2010 - 30\% Initiatives (List the initiatives provided in the 2009-10 tuition differential request.)

Managed at the USF System Level (See USF System Work Plan)

\section{Additional Information (estimates as of April 30, 2010)}

Unduplicated Count of Students Receiving at least one

Tuition Differential-Funded Award:

\$ Mean (per student receiving an award) of Tuition

Differential-Funded Awards:

\$ Minimum (per student receiving an award) of Tuition

Differential-Funded Awards:

\$ Maximum (per student receiving an award) of Tuition

Differential-Funded Awards:

Managed at the USF System Level (See USF System Work Plan) 
University of South Florida - Sarasota-Manatee

SUS Work Plans 2010

STATE UNIVERSITY SYSTEM OF FLORIDA

Tuition Differential Collections, Expenditures, and Available Balances

University: University of South Florida - Sarasota-Manatee

Fiscal Year 2009-2010 and 2010-11

\section{University Tuition Differential}

Budget Entity: 48900100 (Educational \& General)

SF/Fund: 2 164xxx (Student and Other Fees Trust Fund)

\section{Estimated Actual*}

2009-10
Estimated

2010-11

\section{Balance Forward from Prior Periods}

Balance Forward

$\begin{array}{r}\$ 0 \\ \$ 0 \\ \hline \$ 0\end{array}$

Less: Prior-Year Encumbrances

Beginning Balance Available:

\section{Receipts / Revenues}

Tuition Differential Collections

Interest Revenue - Current Year

Interest Revenue - From Carryforward Balance

Total Receipts / Revenues:

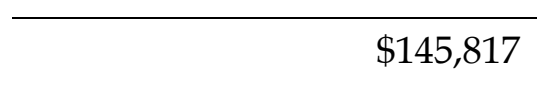

\section{Expenditures}

Salaries \& Benefits

Other Personal Services

Expenses

Operating Capital Outlay

Student Financial Assistance

Expended From Carryforward Balance

**Other Category Expenditures

Total Expenditures:

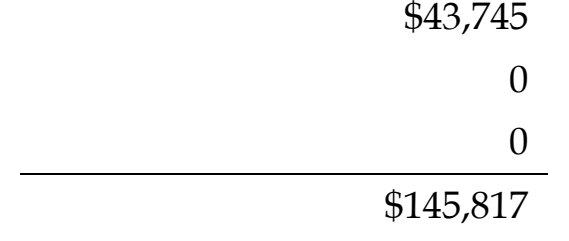

Ending Balance Available:

*Since the 2009-10 year has not been completed, provide an estimated actual.

**Provide details for "Other Categories" used. 
University of South Florida - Sarasota-Manatee

SUS Work Plans 2010

Enrollment Plan Proposal (May need to be submitted later than the rest of the Work Plan)

USF Sarasota-Manatee

\begin{tabular}{|c|c|c|c|c|c|c|c|c|}
\hline $\begin{array}{l}\text { For entire } \\
\text { institution }\end{array}$ & Funded & Estimated & Funded & Estimated & Estimated & Estimated & Estimated & $\begin{array}{c}5-Y e a r \\
\text { Projected }\end{array}$ \\
\hline FTE & 2009-10 & 2009-10 & 2010-11 & 2010-11 & 2011-12 & 2013-14 & $2015-16$ & $\begin{array}{c}\text { Annual } \\
\text { Growth } \\
\text { Rate }\end{array}$ \\
\hline $\begin{array}{c}\text { FL Resident } \\
\text { Lower }\end{array}$ & - & 32 & - & - & - & - & - & \\
\hline $\begin{array}{c}\text { FL Resident } \\
\text { Upper }\end{array}$ & 798 & 966 & 798 & 1,032 & 1,079 & 1,178 & 1,286 & $4.9 \%$ \\
\hline $\begin{array}{c}\text { FL Resident } \\
\text { Grad I }\end{array}$ & 182 & 161 & 182 & 171 & 179 & 196 & 214 & $5.0 \%$ \\
\hline $\begin{array}{c}\text { FL Resident } \\
\text { Grad II }\end{array}$ & - & - & - & - & - & - & - & \\
\hline $\begin{array}{r}\text { Total FL } \\
\text { Resident }\end{array}$ & 980 & 1,160 & 980 & 1,204 & 1,258 & 1,374 & 1,500 & $4.9 \%$ \\
\hline $\begin{array}{l}\text { Non-res } \\
\text { Lower }\end{array}$ & & - & & - & - & - & - & \\
\hline $\begin{array}{l}\text { Non-res } \\
\text { Upper }\end{array}$ & & 16 & & 16 & 16 & 18 & 20 & $5.0 \%$ \\
\hline $\begin{array}{c}\text { Non-res Grad } \\
\text { I }\end{array}$ & & 3 & & 3 & 3 & 3 & 3 & $0.0 \%$ \\
\hline $\begin{array}{c}\text { Non-res Grad } \\
\text { II } \\
\end{array}$ & & - & & - & - & - & - & \\
\hline Total Non-res & & 19 & & 19 & 19 & 21 & 23 & $4.2 \%$ \\
\hline Total Lower & - & 32 & - & - & - & - & - & \\
\hline Total Upper & 798 & 982 & 798 & 1,048 & 1,095 & 1,196 & 1,306 & $4.9 \%$ \\
\hline Total Grad I & 182 & 164 & 182 & 174 & 182 & 199 & 217 & $4.9 \%$ \\
\hline Total Grad II & - & - & - & - & - & - & - & \\
\hline Total FTE & 980 & 1,179 & 980 & 1,223 & 1,277 & 1,395 & 1,523 & $4.9 \%$ \\
\hline
\end{tabular}


University of South Florida - Sarasota-Manatee

SUS Work Plans 2010

For each distinct location (main, branch, site, regional campus) that has or is planned to have more than 150 FTE

SITE: USF Sarasota-Manatee

\begin{tabular}{|c|c|c|c|c|c|c|c|c|}
\hline $\begin{array}{l}\text { For entire } \\
\text { institution }\end{array}$ & Funded & Estimated & Funded & Estimated & Estimated & Estimated & Estimated & $\begin{array}{c}\text { 5-Year } \\
\text { Projected }\end{array}$ \\
\hline FTE & 2009-10 & 2009-10 & 2010-11 & 2010-11 & 2011-12 & 2013-14 & 2015-16 & $\begin{array}{c}\text { Annual } \\
\text { Growth } \\
\text { Rate }\end{array}$ \\
\hline Total Lower & - & 32 & - & - & - & - & - & \\
\hline Total Upper & 798 & 982 & 798 & 1,048 & 1,095 & 1,196 & 1,306 & $4.9 \%$ \\
\hline Total Grad I & 182 & 164 & 182 & 174 & 182 & 199 & 217 & $4.9 \%$ \\
\hline $\begin{array}{c}\text { Total Grad } \\
\text { II } \\
\end{array}$ & - & - & - & - & - & - & - & \\
\hline Total FTE & 980 & 1,179 & 980 & 1,223 & 1,277 & 1,395 & 1,523 & $4.9 \%$ \\
\hline
\end{tabular}

